one on "Sex"- -admittedly a minor topic in the Essais, but they were put on the Index librorum prohibitorum in 1676 on the grounds of obscenity.

This is obviously a book that the reader delves into as the need arises. Not all of the chapters present convincing arguments, but they are all learned, they are all informative, and they all make us think about Montaigne in ways that diverge from tradition. Most importantly, they are almost all stimulating to read.

JOHN MCCLELLAND

Victoria College, University of Toronto

\title{
Erasmus, Desiderius.
}

\section{L'éducation du prince chrétien (ou l'art de gouverner).}

Traduit du latin par Anne-Marie Greminger et présenté par Jean-Christophe Saladin.

Miroir des Humanistes. Paris : Les Belles Lettres, 2016. 260 p. ISBN 978-2-25134610-6 (broché) $25 €$.

C'est un texte précieux et resté longtemps sans traduction en langue française qu'offrent, dans la collection Miroir des humanistes, Anne-Marie Greminger et Jean-Christophe Saladin. Ce texte, c'est l'Institutio principis christianis, traduit ici par la formule "l'Éducation du prince chrétien ", mais qui aurait pu être aussi intitulé l'Institution du prince chrétien ou la Formation du prince chrétien. C'est d'ailleurs cette dernière appellation qu'a préféré très récemment Mario Turchetti qui est le premier à avoir proposé en 2015 une traduction française intégrale de cet ouvrage majeur du prince des humanistes (Paris : Classiques Garnier, 446 p.). Soulignons la joie des érasmiens français qui n'avaient jusqu'à présent aucune traduction disponible de cette œuvre fondatrice et qui, en l'espace de quelques mois, disposent de deux éditions de grande qualité !

Composé par Érasme en janvier 1516 à l'intention du jeune Charles de Gand qui s'apprêtait à devenir roi d'Espagne, ce court traité cherche à agir sur le comportement quotidien du prince. Car ce jeune Charles, qui obtiendra le titre d'empereur en 1519 sous le nom de Charles Quint, a entre ses mains la vie et la mort de très nombreux européens et Érasme, en bon conseiller politique, s'emploie à lui fournir des conseils précis pour l'aider à diriger son royaume 
(modérer les impôts, bien choisir les magistrats...). La thèse défendue par le traité est simple : le prince doit gouverner dans l'intérêt de tous et s'affranchir des désastreuses idéologies de conquête et d'honneur qui n'ont apporté que la ruine aux peuples d'Europe. Reste au prince à appliquer ces recommandations...

La traduction proposée par Anne-Marie Greminger, agrégée de grammaire et passionnée de philologie, est claire, précise, et cherche à traduire au plus juste la pensée érasmienne. Pour ce faire, elle a dû opérer des choix que Jean-Christophe Saladin expose et justifie dans l'introduction du volume : l'expression "respublica» (employée à plus de cent dix reprises dans le traité !) est traduite par exemple non pas par "république " ou "affaires publiques", comme c'était le cas le plus souvent, mais par «État» (15). Afin d'apprécier la finesse de la traduction, tout le volume propose systématiquement le texte latin avec, en face à face, la traduction française. Quelques notes de bas de pages éclairent les points les plus obscurs du texte tandis qu'un appareil critique succinct complète l'ensemble : des notes (237-254) et une bibliographie (une page). L'introduction est stimulante car, même si elle est brève, elle met bien en valeur les enjeux du traité, la qualité du destinataire et de l'auteur, la fortune de ce « miroir », mais aussi la difficulté que pose toute traduction. Néanmoins, le titre donné par les deux auteurs à cette introduction, «l'anti-Machiavel», titre que l'on retrouve également en grosses lettres blanches sur le large bandeau rouge qui ceint l'ouvrage, est maladroit, même s'il a le mérite d'être percutant et attractif. Par ce titre, les deux auteurs cherchent à souligner en priorité à quel point Érasme est un pacifiste dont les convictions en faveur de la paix ne fléchissent pas, même lorsqu'il s'adresse aux plus puissants de son temps. Dans son traité, il oppose en effet sans cesse les arts de la paix à ceux de la guerre et l'exercice de la liberté des citoyens à l'obéissance des sujets. En cela, il se situe dans la plus parfaite contradiction avec son célèbre contemporain Machiavel pour qui il importe que les princes conservent leurs royaumes quel que soit le prix que doivent payer les sujets. Si le choix de cette formule est donc très compréhensible, elle crée cependant quelque peu la confusion car elle évoque le célèbre ouvrage d'Innocent Gentilet, juriste dauphinois passé à la Réforme, qui publie à Genève, après le massacre de la Saint-Barthélémy (1572), un texte fameux intitulé précisément l'Anti-Machiavel en 1576.

Reste que l'essentiel n'est pas là, mais au cœur de ce texte fondateur et si peu connu d'Érasme, qui rappelle que le prince des humanistes fut un homme 
engagé en son temps avec une véritable pensée politique qu'il a offerte et défendue avec espoir et érudition.

MARIE BARRAL-BARON

Université Bourgogne-Franche-Comté

Falkeid, Unn, and Aileen A. Feng, eds.

Rethinking Gaspara Stampa in the Canon of Renaissance Poetry.

Women and Gender in the Early Modern World. Routledge: New York, 2016. Pp. xiii, 222. ISBN 978-1-4724-2706-9 (hardcover) US $\$ 83.96$.

One common pitfall of scholarship on early women writers is to emphasize a female author's biography at the expense of her writing. While Gaspara Stampa's biography is fascinating and thus extremely tempting in this regard, the volume under review successfully manages to emphasize Stampa's artistry. Comprising various articles from the fields of philology, history, gender and women's studies, philosophy, literature, and eco-criticism, Falkeid and Feng's collection builds upon the pioneering studies of the late 1980s and early 1990s by examining how Stampa was in conversation with defining cultural movements of the Renaissance.

To provide the reader with a comprehensive understanding of Stampa's poetry, articles are arranged in relation to the wider intellectual movements with which they are connected. Section 1 focuses on Stampa's dialogue with concepts of the sublime and Cinquecento Neoplatonism. Section 2 concentrates on Stampa's participation in both real and imagined communities. Section 3 examines Stampa's interpretation of the notion of personae.

A particularly noteworthy study is conducted by Jane Tylus's comparative article on Stampa and Sappho. Arguing that Stampa had a sophisticated knowledge of Sappho, Tylus explores Stampa's anxieties regarding her ability to "compete" with Sappho, whose presence dominated sixteenth-century Europe. Tylus intriguingly explores Stampa's sense of inferiority with respect to gender and class, while affirming Stampa's authorial self-confidence. Hence, our understanding of Stampa is simultaneously destabilized and enriched.

Tackling the much-debated topic of how Stampa both assimilates and rejects Neoplatonism in her Rime, Unn Falkeid's study explores Stampa's 